\title{
Green School Program Management in Fostering Students' Character
}

\author{
Syunu Trihantoyo \\ Department of Educational Management \\ Universitas Negeri Surabaya \\ Surabaya, Indonesia \\ syunutrihantoyo@unesa.ac.id
}

\author{
Asmi Leonita Rahma \\ Department of Educational Management \\ Universitas Negeri Surabaya \\ Surabaya, Indonesia \\ asmirahma024@gmail.com
}

\begin{abstract}
Green school programs contribute to creating a comfortable, clean, and healthy school environment. For students, green school programs can also foster environmental cares. This study aims to analyze green school program management in developing environmental caring character in elementary school. Management activities include planning, implementation, and monitoring the implementation of green school programs. Research approach used is qualitative descriptive with case study design. Data were collected using interview, observation and documentation techniques for seven informants: principals, program head, program secretaries, field coordinators, teachers, education personnel, and students. The results showed that green school program planning with an identification of workgroup formation is in accordance with school conditions and needs. The implementation of green school program focused on the working group task to ensure the environmental care value which can be absorbed by students. Monitoring activities to determine the implementation program successfully, by evaluating changes in student behavior. The implementation of this program is implemented by internal and external parties.
\end{abstract}

Keywords-green school program, character

\section{INTRODUCTION}

Learning materials on environmental education should be given early on, so students have an understanding of the environment. Environmental education is expected to educate students to behave towards the environment. Environmental education is a process to build and develop human resources that are aware and care about the environment as a whole with all existing environmental problems. Environmental education is expected to be one of the learning resources available in schools, especially basic education, with knowledge, skills, attitudes, motivation and commitment both individual and collective that can solve various environmental problems in school.

In an effort to accelerate the development of environmental education, especially the formal education path at the level of primary and secondary education, it needs awareness of school personnel, especially learners. Therefore, in February 2006 Adiwiyata Program, a program of the Ministry of Environment, which was then refined to the Minister of Environment Regulation was launched. This program is a form of appreciation given by the government to the formal education institutions that are considered meritorious in developing environmental education.

The implementation of adiwiyata program at the basic education level is closely related to the students as the next generation. Graduates' competence can be seen from the values understood for learners. There are eighteen character values that must be internalized in the educational process according to the Law on National Education System. This study focuses on understanding the nature of environmental care deeply. Caring for the environment is an attitude and action that seeks to prevent damage to the natural environment and its surroundings. It is also related to efforts to repair the already existing natural damage, by safeguarding natural resources and environment. It is an example of an action to environmental caring behavior that students must understand to become a habit.

The results of the preliminary study show that since 2015 a school has realized some greenery program actions, such as changing the school environment into a beautiful environment to support the preservation of the environment by planting shady trees in the schoolyard. In addition, the school has also designed a means of activities to support the implementation of adiwiyata program. The program includes greening the surrounding environment including planting in each class, biophore use and electricity savings. The uniqueness encountered in the school is that the students are trained to make hydroponics made of used bottles. The adiwiyata program teams have provided guidance on hydroponic plants, which are included in the activities of the adiwiyata program. This makes researchers interested in researching the management of green school programs in growing the character of students, where management is concerned with planning, actuating and monitoring.

\section{LITERATURE REVIEW}

Management is very important for every individual or group activity within the organization to achieve the desired goals. Process oriented management means that management requires human resources, knowledge, and skills to make activities more effective or can result in action in achieving success. 


\section{A. The Green School Program Concept}

Green School was first used for an Ecological School Plan proposed by the Foundation of European Environmental Education (FEEE). At that time, the purpose of implementing green school is the implementation of school environmental management system can support the management of school management activities every day.

Along with technological developments, in 2007, United States Green Building Council (USGBC) launched National Green Schools Campaign, and they support green schools for everyone within this generation. Zhao, et al. [1] argued that the concept of green school is not only related to school management, but also to the basic requirements of green school, i.e. energy efficiency, resources efficiency and $\mathrm{CO} 2$ emissions reduction, as shown in Figure 1.

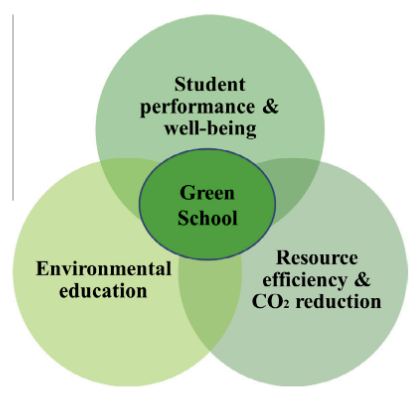

Fig. 1. Figure 1 The basic scheme of green school

In 2009, USGBC launched LEED for Green Building Rating System for Schools New Construction and Major Renovations, which addresses seven topics: Sustainable Sites, Water Efficiency, Energy and Atmosphere, Materials and Resources, Indoor Environmental Quality, Innovation in Design and Regional Priority. With gradual improvement, LEED for School has been adopted by Indonesia and other countries such as Canada, India, Saudi Arabia, Malaysia, and China.

In Indonesia, green school program is aligned with the policies and regulations of the Environment Minister with the National Education Minister in order to establish the nation's character for sustainable development. This program is known as 'Adiwiyata'. Adiwiyata program can provide support for sustainable development and create a comfortable, clean, healthy and fun school condition so that the learning process in school can be achieved well. This is similar to Dayal [2] opinion that the Educational program provides a wide range of knowledge, which helps a person understand the environment in which he functions. They help individuals to relate in context with a given situation. After attending an educational program it is expected that the individual is able to understand the totality better, get better direction and deal with the situation.

\section{B. Components and Standard of Adiwiyata Program}

There are four components to achieve Adiwiyata program which has been prepared by National Level Adiwiyata Team (2012) which is a compound of the program into a unified whole in reaching school based environment or based on adiwiyata. The four components are; 1) environmental policy; 2) the implementation of an environment-based curriculum; 3) Participatory based environmental activities; 4) management of environment-based school facilities.

Another opinion suggests that the basic function of green school is to improve the efficiency of energy and resources use and reduce carbon emissions; secondly, the green school aims to create a healthy, comfortable and sustainable school space, intending to improve the indoor comfort and students' performance (Zhao, et al. [1]).

\section{Adiwiyata School}

Creating an environmentally sound school (adiwiyata) is a school commitment in internalizing environmental values into all school activities. The school display is ecologically arranged so that it becomes an effective tool for the students' educational process. A conducive school environment is needed to create a quality learning process (Karwati and Priansa [3])

Based on adiwiyata school definition above it can be concluded that the Adiwiyata School is an environmentally sound school with which school commitment systematically develops programs to internalize environmental values into all school activities. The physical appearance of the school is ecologically arranged so that it becomes a learning vehicle for all school personnel, especially students to be wise and behave environmentally friendly. Providing knowledge and awareness, rising on clean and healthy life behaviors is very effective when students are in primary school. A conducive school environment is needed to create a quality learning process.

\section{Environmental Caring Character}

Within the framework of character building, environmental care becomes an important value to grow. Human character is a human being who has concern for the environment, both the social and physical environment. The understanding character is not solely the innate talents of individuals, but is the result of human formation and the environment of living, life, and being raised. Education is the most conducive place in shaping character. This is because the character of environmental care is a form of individual mental attitude that is reflected in behavior.

\section{METHODS}

The research method used was a descriptive qualitative approach with case study research design to observe, study, and analyze green school program management in fostering students' character. The research was conducted at the primary school. Data sources included primary and secondary data. The data were collected using interview technique, observation, and documentation to seven informants, i.e. principals, program chiefs, program secretaries, field coordinators, teachers, education personnel, and students.

This study used a research procedure that begins with field studies to formulate a research focus. Field studies were conducted related to a literature review, problem identification, 
problem formulation, and limitation. After the problem/uniqueness and the restrictions of research were found, then the focus of research was formulated, i.e. related to the green school program management in fostering students' character. At this stage, the researcher designed the data collection through an interview, observation, and documentation study.

The researchers then collected data on the field and continued with condensation data. Data condensation refers to the process of selecting, focusing, simplifying, abstracting, and/or transforming the data that appears in the full corpus (body) of written-up field notes, interview transcripts, documents and other empirical materials (Miles, et al. [4]).

\section{RESULTS AND DISCUSSION}

Green school programs are a way to make learners care about nature. Learning the value of environmental cares and clean and healthy lifestyle early on can make students become familiar and as a good habit formation for them in a school environment, home and society.

\section{A. Planning Green School Program in Fostering Students Character}

Planning activity is the first step in implementing green school program. The results of the research about adiwiyata program planning show that the principal makes a need analysis in the creation of green school program. Such identification results in a program that is distributed in fourteen main work programs. This is described in the following figure.

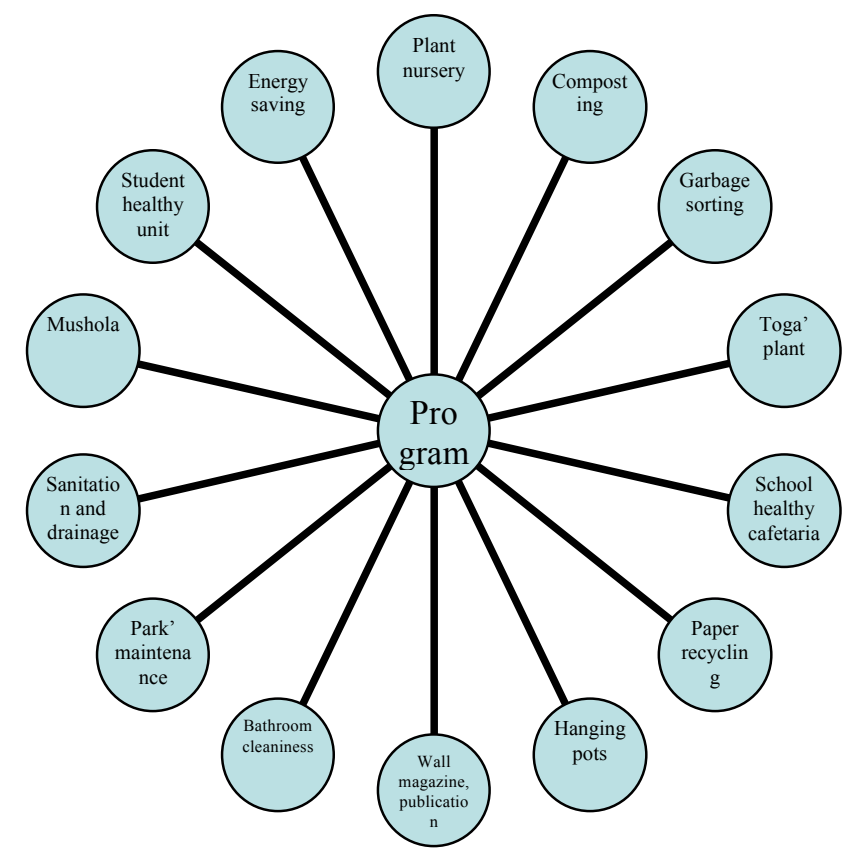

Figure 2 Green school program.

Figure 2 above shows that green school programs implemented by schools is as an effort to establish environmental caring character by implementing the program:
1) plant nursery; 2) composting; 3) place provision and garbage sorting; 4) toga plant; 5) school healthy cafeteria; 6) paper recycling; 7) hanging pot; 8) wall magazine and publication; 9) bathroom cleanliness; 10) garden maintenance; 11) sanitation and drainage; 12) musholla; 13) student health unit; 14) energy saving.

In order to ensure the overall program runs, the principal creates an organizational structure with each member assigned to each program. This structure consists of fourteen work centers of adiwiyata program. Another effort is to create a time schedule that is implemented within a predetermined period of time as well as budgeting funds as a supporting system. Schools empower partners in the implementation of green school programs. Some of these instances are District Environmental Agency, the District Government, and the community.

\section{B. Implementation of Green School Program in Fostering Students' Character}

Green school program activities were implemented during the learning activities. In addition, students also move outside the classroom or school ground. School grounds have potential as a rich resource for formal learning; they are outdoor classrooms that can be extended and explored by children outside classroom time (Malone and Tranter [5]). The process of character growth can be internalized by students through repetitive habituation. The habituation will become a culture in school, especially culture to behave environmentally friendly. In the process of habituation for elementary education level it requires the role of teacher counselor (Dyment [6]; Scott, et al. [7]; Martin [8]).

Green school program implementation activities in schools are implemented in accordance with the program plan that has been prepared. Each program has a load of character values that will be implanted in the student self. The school provides sufficient time in between learning activities. Every day the students are asked to pick up the garbage that is around them. Concern for the plants is actualized by watering and caring for hanging pots of students' work. This hanging pot is placed in front of the class. Students can monitor plant growth.

Figure 4 shows the students' caring character. Implementation of hanging pot was made and treated by students. Therefore, students will grow a sense of ownership through habituation to always maintain, care for and preserve a healthy, clean, and beautiful environment. Bell and Dyment [9] describe green school is an umbrella term used here to refer to a range of changes occurring on school grounds including gardening, naturalization, habitat restoration, tree planting and other collaborative efforts to bring nature back to the school ground.

A green school program that has been implemented in primary schools is the implementation of the vision, mission, and school goals. The success of green school program can be seen from the activities of students in behaving every day, i.e. students are more disciplined and care about the cleanliness and neatness of the school environment. The sustainability of the green school program is also followed up with similar activities in the home environment. Thus, the students are able 
to continue their own greening habits in the neighborhood and community.

\section{Monitoring Green School Program in Fostering Students' Character}

Monitoring is the final act in management. Therefore, monitoring has an important role to know whether the implementation of the program runs according to plan. Monitoring activities serve to ensure that the conformity of the established objectives has been achieved. Monitoring of green school program at school has been running. This was done by Environment Agency, Public Health Center. Then, supervision was conducted by internal and external.

Monitoring results show that green school environment provides an opportunity to develop important lessons on cooperation, ownership, belonging, respect and responsibility. School grounds also convey messages to children about school ethos that can influence their attitude and behavior (Malone and Tranter [5]). The character value can be applied by the students through the activity of habituation by design. The result of green school implementation is also related to the relationship of school personnel because green school is not only related to environment-based school management. Green schools can play an important role in enhancing social health by providing a more diverse environment that better response to the needs and interests of more children and by creating opportunities for students, staff, and parents to work together towards shared goals (Bell and Dyment [9]).

The stage of planning and implementation of the program is in accordance with the procedure although there are obstacles in its application, primarily about the schedule between learning activities with the implementation of the green school program in the field. The implementation of fourteen programs above required considerable time. Meanwhile, schools also need to implement the material that has been contained in the curriculum.

However, schools have a solution to the problem. On Saturday, students are more focused on green school program implementation activities in the field. Outdoor learning is as an alternative vision of education that should be seen as essentially different from traditional schooling, rather than an extension of schools (Rea [10]). Thus, there is a balance between the planting of environmentally caring character and learning activities into a complementary unity.

\section{CONCLUSIONS}

Green school program in the realization of Adiwiyata School is one way to make students care about nature. By planting the value of environmental caring character since elementary school through habituation in a school environment, home, and society, it will become a clean and healthy lifestyle. Students who have grown up in this environment will bring their learning to their homes and communities, thereby contributing to the green world (Meiboudi, et al. [11]). For managing program, the activities include planning, implementation, and monitoring.

\section{REFERENCES}

[1] D.-X. Zhao, B.-J. He, and F.-Q. Meng, "The green school project: A means of speeding up sustainable development?," Geoforum, vol. 65, pp. 310-313, 2015.

[2] I. Dayal, "A perspective of professional management education," Paradigm, vol. 12, pp. 1-4, 2008.

[3] E. Karwati and D. J. Priansa, "Manajemen Kelas (Classroom Management): Guru Profesional yang Inspiratif, Kreatif, Menyenangkan, dan Berprestasi," CV. Alfabeta, Bandung, 2014.

[4] M. B. Miles, A. M. Huberman, and J. Saldana, Qualitative data analysis: Sage, 2013.

[5] K. Malone and P. J. Tranter, "School grounds as sites for learning: Making the most of environmental opportunities," Environmental Education Research, vol. 9, pp. 283-303, 2003.

[6] J. E. Dyment, "Green school grounds as sites for outdoor learning: Barriers and opportunities," International Research in Geographical \& Environmental Education, vol. 14, pp. 28-45, 2005.

[7] W. Scott, A. Reid, and N. Jones, "Growing schools: The innovation fund projects (2002-2003). An external evaluation," ed: Bath, UK: Council for Environmental Education and University of Bath, 2003.

[8] S. C. Martin, "The influence of outdoor schoolyard experiences on students' environmental knowledge, attitudes, behaviors, and comfort levels," Journal of Elementary Science Education, vol. 15, pp. 51-63, 2003.

[9] A. C. Bell and J. E. Dyment, "Grounds for health: the intersection of green school grounds and health-promoting schools," Environmental Education Research, vol. 14, pp. 77-90, 2008.

[10] T. Rea, "Alternative visions of learning: Children's learning experiences in the outdoors," Educational Futures, vol. 1, pp. 42-50, 2008.

[11] H. Meiboudi, A. Lahijanian, S. M. Shobeiri, S. A. Jozi, and R. Azizinezhad, "Creating an integrative assessment system for green schools in Iran," Journal of Cleaner Production, vol. 119, pp. 236-246, 2016. 